\title{
Functional Approaches for Applying Work- based Learning into Electrical and Electronic Technology Education in Nigeria
}

\author{
Rabiu Haruna, Yusri Bin Kamin ,Yahya Bin Buntat, Halliru Shuaibu , Abdullahi Musa \\ Cledumas
}

\begin{abstract}
The study examined functional approaches for applying work-based learning (WBL) into Electrical and Electronic Technology (EET) in northwest Nigeria. Survey research design was adopted to carry out the study. Random sampling technique was used to select two tertiary institutions offering Electrical and Electronic Technology. The entire 32 lecturers of EET from the two tertiary institutions and 64 supervisors of registered Electrical Technology firms in the two states making a total of 96 respondents were used for the study. Data were obtained using structured 48-item questionnaire titled 'Functional Approaches for Applying Work-based Learning Questionnaire (FAAWBLQ)'. Data collected were analyzed using descriptive statistics such as frequency, percentages and mean ratings. In interpreting the results, work-based learning experience with percentage score of $50 \%$ and above were interpreted as 'Practiced' while those with less than 50\% were interpreted as 'Not Practiced'. Using 2.50 as the cut-off point, items with mean values of 2.50 and above were interpreted as 'Agreed'. The results of the study showed that only 2 out of the 17 identified work-based learning components were practiced for skill acquisition in Electrical Technology in Northwest Nigeria. In addition, the study identified administrative, school-industry and resource inputs approach for effective application of WBL that will guarantee skill acquisition in Northwest Nigeria. The study recommended policies to strengthen a dynamic and robust WBL in technical and vocation education (TVE) in Nigeria and that work-based learning framework in Nigeria be carefully developed and overseen by Industrial Training Unit (ITU) of education sector to coordinate the synergy between training institutions and industry for improved skill acquisition of the teaming Nigerian youths.
\end{abstract}

Key Words: Functional approach, work-based learning, electrical technology education

\section{INTRODUCTION}

Technical and vocational education (TVE) is the form of education that offers the required skills, knowledge and attitude that result to the production of individual that are skillful and productive after the training. Brodie and Irving

Revised Manuscript Received on April 19, 2019.

Rabiu Haruna, Department of Technical and Engineering Education, School of Education, Faculty of Social Sciences and Humanities, Universiti Teknologi Malaysia, Johor Bahru, Johor, Malaysia.

Yusri Bin Kamin, Department of Technical and Engineering Education, School of Education, Faculty of Social Sciences and Humanities, Universiti Teknologi Malaysia, Johor Bahru, Johor, Malaysia.

Yahya Bin Buntat, Department of Technical and Engineering Education, School of Education, Faculty of Social Sciences and Humanities, Universiti Teknologi Malaysia, Johor Bahru, Johor, Malaysia.

Halliru Shuaibu, Department of Technical and Engineering Education, School of Education, Faculty of Social Sciences and Humanities, Universiti Teknologi Malaysia, Johor Bahru, Johor, Malaysia.

Abdullahi Musa Cledumas, Department of Technical and Engineering Education, School of Education, Faculty of Social Sciences and Humanities, Universiti Teknologi Malaysia, Johor Bahru, Johor, Malaysia.
[1] affirmed that TVE emphasizes skills, knowledge and attitudinal acquisition for improved productivity and selfreliance through expertise in areas such as Electrical Technology among others. Electrical Technology Education (ETE), according to Ismail, Mohamad [2], is a programme of instruction that equips students with in-depth understandings of electrical and electronic knowledge and skills through the integration of theoretical and practical courses. Electrical Technology as described by Monroe Career and Technical Institute [3] is a form of education that prepares individuals to apply technical knowledge and skills necessary to install, operate, maintain and repair electricallyenergized residential, commercial and industrial systems. Similarly, Aggeliki [4] observed that Electrical Technology deals with machines, DC and AC motors, tools, devices and electrical system technologies in which a current or a stream of electrons happens through conduits and metals. It includes the plan of high-voltage systems and segments, for example, engines, generators, heaters, electrical power transmission and dispersion frameworks, radio wave and optical frameworks, converters, and control systems for working light and overwhelming device.

Electrical Technology however, not only involves the design and production of electrical systems but also the installation, testing and training of manpower for maintenance of the systems. For instance, Aderonmu [5] reported that, the teaching and learning of Electrical Technology emphasizes practical application of Mathematics, Science, circuit diagrams and use of electrical codes, blueprint reading, sketching and other subjects essential for employment in the electrical occupations. Okoro [6] stated that ETE is today offered in polytechnics, colleges of education and universities with the aim of acquainting individuals with knowledge, skills and attitudes that make them functional members in the world of work, thereby contributing to nation building. Okoye and Arimonu [7] argued that TVE in Nigeria cannot play a role significantly to the reduction of horrible poverty, unemployment and hunger as it is impeded by various difficulties. Ineffective school-industry linkage constitutes part of the major challenges of TVE in Nigeria. Oranu [8] observed that the well-meaning plans of progressive Nigerian governments about TVE projects are harmed with a lot of difficulties. Okoye and Arimonu [7] noted further 
that available facilities and programmes of instruction of Nigerian TVE are inadequate quantitatively and qualitatively. Oryem-Origa [9] revealed that under $40 \%$ of establishments of higher learning in Nigeria have research center or workshop space for specialized training programs while the remaining institution having almost $60 \%$ don't have laboratory and this has come about to the low quality of TVE in Nigeria.

The present teaching and learning of TVE in Nigeria are basically theoretical through classroom instruction with little or no attempt to balance classroom instruction with skillbased learning. This has further aggravated rate of unemployment among Nigerian graduates due to inadequate acquisition of skills during training. According to Ezeji, Edeh [10], the high rate of joblessness and other economic adversity in developing nations like Nigeria have transpired to improbable concern. The Nigerian youth population is almost a hundred million representing about $60 \%$ of the total population [11]. By implication, Nigerian youths constitute active player in the growth and development of country. Youth unemployment index in Nigeria has increased significantly due to lack of relevant marketable skills for self or paid jobs in Nigerian labour market. The increasing rate of unemployment among Nigerian youths is part of the factors responsible for the escalating poverty index, rising crime and anti-social behaviours. This draw back implies that TVE programmes in Nigeria are being rendered to: mere suppliers of semi-skilled or not-at-all-skilled labour to the job market; inability to train students with requisite knowledge, attitude and skills [12]. These problems originated due to the absence of a framework for embedding WBL into technical and vocational education, Electrical and Electronic Technology inclusive, at tertiary education level in Nigeria.

Although, different government mediations have been set up in Nigeria to mitigate the issue of joblessness and destitution among the citizens, numerous graduates of various educational dimensions particularly the tertiary dimension remain at home quite a long while after graduation without a living employment. Despite the fact that the Nigerian government has perceived professional training as an instrument for poverty alleviation among the citizens, yet joblessness is expanding and poverty level in the nation is about $72 \%$ [13]. Subsequently, there is a critical requirement for a viable round table talk on fortifying TVET in Nigeria to reasonably meet the workrelated experience need of Nigerian youths through workbased reengineering of the system. It ought to be noticed that effective skills instructing has enormously added to the innovative excellence and economic self-reliance of the developed nations [14]. For TVE learners to be productive on graduation there must be great association between theories and practice. Practice based learning spurs learners to learn, and this must be conceivable when the methodology of instruction and learning of technical and vocation education are moved from the conventional strategies to an increasingly dynamic methodology and ability situated culture, for example, work-based learning.

Exposing learners to WBL approach therefore advances information exchange, in as much as students are helped with creating teamwork skills. Okon [15] depicted WBL as an experiential learning program that utilizes the workplace as a critical segment of the educational modules to supplement classroom instructions. Work-based learning is an instructional plan in which students are simultaneously presented to supervision in both industry and school conditions. Through work-based learning, organized learning encounters are given to students by synergistic endeavors of supervisors of work place and the school. As per Jerrard and Jefsioutine [16] work-based learning forges a considerable connection between classroom guidance and the universe of work to ensure the acquisition of necessary skills needed by workplace environment. Amadi [17] advocated the essentialness of WBL that it offers students the basic chance to appreciate how classroom instruction relates to work-world and future vocational prospects.

In explicit terms, WBL makes affirmation for dynamic cooperative investment of students, teachers, managers and suitable offices bringing about the advancement of learning and work-place skills, inspiration of learners for quality learning, improved employability of graduates, just as students' capacity to distinguish profession pathways on graduation. Kamin, Latib [18] saw that, as a working environment learning condition, the use of the WBL program truly includes genuine encounters when it changes theory into practice in the work place environment. Schrenko [19] opined that WBL program incorporate work experience opportunities, work training and work encounters facilitated with both scholarly and work-related learning in school-based projects that are pertinent to students' program of study for profession advancement.

Career enhancement is a segment of WBL that opens students to varieties of work settings to help them in decision making about future profession heading and occupations as practiced in industrialized nations. Virginia Department of Education [20] revealed that WBL assembles vocation and school status through a continuum of encounters intended to cultivate improved instructive results for students with inabilities. This continuum may incorporate experiences in the accompanying four areas of exploration, awareness, preparation and training. It is basic to express that notwithstanding the mind-boggling acknowledgment of the jobs of TVE in advanced country, there is clear frail linkage between Nigerian TVET institutions and industry for procurement of required abilities and capabilities for work. Subsequently, so as to locate an enduring arrangement, this examination observationally explored practical methodologies for applying work-based learning into EET in Nigeria. In particular, the identified the current work-based learning experience for successful skills procurement in Nigeria, the noteworthiness of authoritative, school-industry and resource inputs way to deal with viable WBL structure into Electrical and Electronic Technology in Nigerian TVET system. 


\section{LITERATURE REVIEW}

Work-based learning is an institutional strategy in which students are simultaneously presented to both work in industry and learning in school conditions for skills acquisition for work. Work-based learning in the words of Boud and Solomon [21] is the term being utilized to depict programs that unite colleges and work place to make new learning in working environments. A further depiction of work-based learning was given by Mohamad, Hamdan [22] as a learning plan where students are full-time representatives whose programmes of study are completely implanted in the work environment and is intended to meet the adapting needs of the workers and organization. Lemanski, Mewis [23] recognized that WBL system is a fundamental part in the progressing and future development of the present workforce. Likewise, Amadi [17] expressed that WBL avails student' learning opportunities to acquire skills upon introduction to thorough academic engagement at the same time with hands-on profession development experiences.

Conceptualization of WBL legitimately underpins discipline-based learning that shapes the premise of higher and skilled based training. It additionally proposes work learning that happens in a more extensive and basically transdisciplinary or post-disciplinary system that can fuse disciplinary learning [2]. Work-based learning is one of the learning structures that has been drilled most particularly in developed nations of the world and meets towards the theory of constructivism. It is a functioning and dynamic type of learning that gradually creates all through the lifetime of an individual student. Work-based learning is proper for use in tertiary education and reasonable in technical and vocational education and training, however not for schemes that are not skilled based instructions. Becker [24] illustrated workbased learning as an approach that envelops a working experience in which learners need to get experience through a learning procedure in an institution to pick up the experience and apply the skills in the related work as per what is required in a workplace environment. As indicated by Fleming and Martin [25], work-based learning technique is a term utilized for students in school level with the end goal for them to acquire experience through work and learning by training. It empowers students in preparing establishments to adjust with the institutional change to work and opens them to the truth of the workplace that enables them to settle on the best vocation decision on graduation from preparing foundations.

Work-based learning programs are displayed in an assortment of approaches to furnish students with learning background in the work-world as to ensuring inevitable smooth change to the universe of-work upon graduation. Lemanski, Mewis [23] revealed that learning for work can include the students to setting out on work-experience position where they would be effectively associated with the procedures of the work environment. Schrenko [19] revealed that a portion of the work-based learning programs significant to TVET incorporate industrial training, field trips, excursion, work shadowing, school-based endeavors etc. Also, the report of Virginia Department of Education [20] recorded instances of work-based learning encounters to include: work environment visits, job shadowing, service

learning, field trips, guest speakers, employer presentations, career fairs, business mentorships, volunteering, job training, student run enterprises, work-study programmes, school-based enterprise among others. Work-based learning manages students' satisfactory learning open doors for aptitudes obtaining that ensures synergistic connection between the school and industry in the realm of-work. It creates opportunity for closing the gap that exists between theory and practice, hence, making meaningful and functional skill-based learning possible. Lemanski, Mewis [23] identified a set of criteria for the success of WBL experience which include: (i) solid program leadership, (ii) associations between the program and its environment (iii) effective school-based learning component, iv) frequent and effective communications with local employers, (v) beliefs about programme excellence, (vi) adequate financial support and (vii) innovative programme and pedagogical features. As indicated by White [26], the six noteworthy essentials for an effective WBL are:

a) the WBL programme should be jointly developed by the head of higher institution and the employer,

b) continuous correspondence between the employers, workers and scholastics,

c) full duty from the employers, workers and scholastics,

d) cultural obstructions should be distinguished and survive,

e) the worker must be upheld by both the institution and the employer; and

f) flexibility of delivery and appraisal.

A. Work-based Learning and Quality of Technical and Vocational Education

Word related progression of students is an essential segment of WBL that opens the students to an assortment work setting to helps them in settling on choices about future professional opportunity and occupations. This is on the grounds that, work-based adds to big business efficiency and development [1]. The estimation of WBL as a type of learning professional instruction and preparing identifies with its criticalness in improving youth advances and vocation improvement. It is imperative to state that WBL approach makes significant contribution to the productivity of firms and improvement in innovation of technological firms and enterprises. The interior association of firms, the course of action and association of work, worker relations and pay structures would all be able to collaborate to upgrade quality learning and consequently to expand increase productivity and innovation of technical and vocational education [27].

The rich learning environment created by work-based learning contribute to advancement in technology and innovation within enterprises [28]. Work-based learning approaches are very important in TVET to develop basic work habits and skills, occupational identity and specific occupational competences needed in the world of work [1]. 
However, due to the attractiveness and interactive nature of WBL in technical and vocational education, it can be used for a wider range of educational purposes. For instance, Stainsby and Bannigan [29] noted that work-based learning has the capacity to stimulate the interest of disadvantaged and discouraged learners by giving them the chance to experience accomplishment through connected learning in practical settings, and the opportunity to interact with grown-up mentors and role models in skill-based learning environment. In addition, the benefits of WBL experiences also reflect in informed career decision-making that can be amplified when learners have the opportunity to reflect on their learning experience and share it with others [27]. Work-based learning avails youths with widespread opportunities to combine learning and work to effect successful career transition in the labour market.

Work-based learning within the context of technical and vocational education and training are largely based on the superior quality and relevance of the skills that are developed through involvement of the learners in the production of real goods and services [30]. It is difficult, to imitate the genuine requests of day by day generation, or the cycle of production over some stretch of time, in a study hall or workshop, and neither can these settings effectively repeat the social setting of work that emerges from connecting with coworkers and from managing clients and providers[1]. Co-operation and Development [27] revealed that workshops and classrooms can only with significant effort repeat the setting in which skills should be connected through work-based learning.

Further advantages of work-based learning in TVE are that it effectively includes the students during the time spent in technical and vocational education and training, accordingly expanding their trust in the system, and expanding the connection among students and the work showcase so as to improve their odds of work on graduation from their training institution. Deitmer [28] expressed that there is additionally an economic advantage for utilizing WBL in technical and vocational education and training. This is on the grounds that, the way toward exchanging the expense of accomplishing taking in results from openly supported educational institutions to organization results in a reducing in public expenditure and ability to use a given level of funds more effectively to achieve wider participation in education and training [1]. Learning approach, for example, work-based discovering that utilizes gear and offices on students and business premises results in refreshed modern practices, in this way prompting skills with more remarkable relevance at decreased expense. The case for WBL is regularly made as far as the advantages that it can accommodate professional instruction and preparing.

\section{METHODOLOGY}

\section{A. Design}

The study adopted survey research design to sample the opinions of respondents using structured questionnaire. Survey research design according to Check and Schutt [31] is the collection of data from an example of people through their reactions to questions. Ponto [32] noticed that overview research can utilize quantitative research methodologies utilizing polls with numerically evaluated things, subjective research procedures utilizing open-finished inquiries, or the two systems for information gathering. The investigation was done in Northwest Nigeria, made up of seven states which include: Kaduna, Kebbi, Sokoto, Katsina, Zamfara, Kano, Jigawa.

\section{B. Sampling Procedure}

Random sampling technique was used to select two states which are Kaduna and Kano States out of the seven states in northwest Nigeria. Two tertiary institutions (Federal College of Education, Bichi, Kano State and Kaduna State Polytechnics) offering Electrical and Electronic Technology Education were purposively sampled. The entire 32 lecturers of Electrical and Electronic Technology from the two tertiary institutions were involved as respondents in the research in addition to 64 supervisors of registered Electrical Technology firms in the two states. This made the total sample for the study amount to 96 respondents.

\section{Instrument}

Data for this study were obtained using structured close-ended questionnaire titled 'Functional Approaches for Applying Work-based Learning Questionnaire (FAAWBLQ)'. The instrument was content and facevalidated by three senior lecturers and two industry-based supervisors in Kaduna and Kano States, northwest Nigeria. The questionnaire was structured on four-point response options of: Strongly Agree (SA), Agree (A), Disagree (D) and Strongly Disagree (SD) with equivalent values of 4, 3, 2 and 1 respectively.

\section{Estimation Procedure}

Data collected were analysed employing descriptive statistics. To take decision on current workbased learning practices in the study area, 50\% was used as benchmark [33]. Therefore, any work-based learning experience with percentage score of $50 \%$ and above were interpreted as 'Practiced' while those with less than 50\% were interpreted as 'Not Practiced'. On the major approaches for applying work-based learning in Electrical and Electronic Technology in northwest Nigeria, criterion reference point of 2.50 was used on four-point rating scale. Hence, items with mean values of 2.50 and above were interpreted as 'Agreed' while those with mean values of less than 2.50 were interpreted as 'Disagreed'. 


\section{RESULTS AND FINDINGS}

Table 1: Distribution of Work-based Learning Practices for EET Skill Acquisition

\begin{tabular}{|c|c|c|c|c|c|}
\hline $\mathbf{S N}$ & Work based learning practices & Freq. & Perc. (\%) & Remark & Ranking \\
\hline 1 & Field trips & 77 & 80.21 & Practiced & $1^{\text {st }}$ \\
\hline 2 & Workplace tours & 68 & 70.63 & Practiced & $2^{\text {nd }}$ \\
\hline 3 & Paid employment & 48 & 45.21 & Not Practiced & $3^{\text {rd }}$ \\
\hline 4 & Apprenticeships & 39 & 40.63 & Not Practiced & $4^{\text {th }}$ \\
\hline 5 & Paid and unpaid internships & 37 & 38.54 & Not Practiced & $5^{\text {th }}$ \\
\hline 6 & School-based enterprise & 35 & 36.45 & Not Practiced & $6^{\text {th }}$ \\
\hline 7 & Job training & 33 & 34.38 & Not Practiced & $7^{\text {th }}$ \\
\hline 8 & Work-study programmes & 32 & 33.33 & Not Practiced & $8^{\text {th }}$ \\
\hline 9 & Service learning & 28 & 29.17 & Not Practiced & $9^{\text {th }}$ \\
\hline 10 & Cooperative work experience & 27 & 28.13 & Not Practiced & $10^{\text {th }}$ \\
\hline 11 & Student run enterprises & 24 & 25.00 & Not Practiced & $11^{\text {th }}$ \\
\hline 12 & Mentoring & 22 & 22.92 & Not Practiced & $12^{\text {th }}$ \\
\hline 13 & Volunteering & 21 & 21.87 & Not Practiced & $13^{\text {th }}$ \\
\hline 14 & Career fairs & 20 & 20.83 & Not Practiced & $14^{\text {th }}$ \\
\hline 15 & Employer presentations & 19 & 19.79 & Not Practiced & $15^{\text {th }}$ \\
\hline 16 & Business mentorships & 18 & 18.75 & Not Practiced & $16^{\text {th }}$ \\
\hline 17 & Job shadowing & 15 & 15.63 & Not Practiced & $17^{\text {th }}$ \\
\hline
\end{tabular}

Source: Field Survey, 2019

The result in Table 1 presents frequency and percentage distribution of different work-based learning practices utilized for Electrical Technology skill acquisition in Nigeria. Two out of the 17 identified work-based learning experiences were practiced in Electrical Technology skill acquisitions having percentage values greater than 50\% which include: field trips $(80.21 \%)$ and workplace tours (70.63\%). Ismail, Mohamad [2] assessed awareness of technical and vocational education and training (TVET) teacher trainers of work-based learning and identified the common components to include: cooperative work experience programme, field trips, job shadowing, schoolbased enterprise, entrepreneurial ventures, youth apprenticeship and internship. Similarly, the report of Virginia Department of Education [20] identified WBL experiences mostly adopted as workplace tours, field trips, job training, apprenticeship, internship and school-based enterprise. Amaechi and Thomas (2016) recommended field-trip as part of the method of straightening WBL in TVET system.
On the other hand, the remaining 15 work-based learning experiences were not practiced for Electrical Technology skill acquisition having percentage values less than 50\% which include: work-study programmes (38.54), service learning (34.38), cooperative work experience programme (29.17), student run enterprises (25.00), guest speakers (22.92), volunteering (21.87), career fairs (20.83), employer presentations (19.79), business mentorships (18.75), apprenticeships (40.63), school-based enterprise (36.45) and job shadowing (15.63). Hence, the rate of practicing these work-based learning components for effective skill acquisition in Electrical Technology is low. Mark [34] reported that the rate of adoption of WBL in Nigerian VTE is still relatively low as most teaching is theoretical in classroom setting. Amaechi and Thomas [35] justified that technical and vocational education institutions in Nigeria should not rely on the theory-based methods of teaching, because imparting practical skills is paramount which can be achieved through work-based learning. There should be adoption of effective measures to imparting the required knowledge, attitudes and skills for the individual to function efficiently in the society.

Table 2: Administrative approaches for effective work-based learning in EET in Nigeria

\begin{tabular}{|c|c|c|c|c|c|c|c|}
\hline SN & Variables & Obs. & Mean & SD & Max. & Min. & Remarks \\
\hline 1 & $\begin{array}{l}\text { Setting of industrial advisory committee for } \\
\text { implementation of work-based learning programme }\end{array}$ & 96 & 3.69 & 0.58 & 4.00 & 1.00 & Agreed \\
\hline 2 & $\begin{array}{l}\text { Formulation of law by Government agencies to } \\
\text { compel TVET firms for cooperation with training } \\
\text { institution. }\end{array}$ & 96 & 3.61 & 0.49 & 4.00 & 3.00 & 66 \\
\hline 3 & $\begin{array}{l}\text { Mandate ITF to regulate students posting to } \\
\text { industries of relevance for work-based learning }\end{array}$ & 96 & 3.69 & 0.48 & 4.00 & 2.00 & 66 \\
\hline
\end{tabular}


International Conference on Recents Advancements in Engineering and Technology (ICRAET-18) |15th and 16th March 2019|Siddhartha Institute of Technology \& Sciences, Telangana, India.

4 Retooling Electrical and Electronic Technology workshops to replicate modern world of work workshops.

$5 \quad$ Ensuring that VTE firms hosting students training enjoy tax rebate from government.

6 Develop and integrate central industrial training examinations for students on work-based learning

7 Supporting students on work-based learning with monthly stipend by the government.

8 Allowing students on training guided access to require occupation information.

9 Setting up industrial coordinating board to enhance cooperation between institutions and Electrical and Electronic Technology firms.

10 Improve the administrative practices of industrial liaison offices of technical training institutions.

11 Ensure work-based learners' adequate access to industrial facilities, equipment and machines.

Source: Field Survey, 2019The result in Table 2 shows that the mean ratings of the responses of supervisors and lecturers of Electrical and Electronic Technology on the 11 identified items ranged from 3.29 to 3.70 which are greater than the criterion reference point of 2.50 on 4-point rating scale. This indicates that the identified 11 items in the table signified administrative approaches that could be utilised for effective work-based learning in Electrical Technology in Nigeria. Strong administrative approaches play significant roles in effectiveness of technical and vocational education. Jimoh, Maigida [36] identified administrative strategies for creating linkage between TVET institutions and the industry

$\begin{array}{cccccc}96 & 3.44 & 0.56 & 4.00 & 1.00 & \text { “ } \\ 96 & 3.29 & 0.52 & 4.00 & 1.00 & \text { “ } \\ 96 & 3.47 & 0.52 & 4.00 & 2.00 & \text { “ } \\ 96 & 3.66 & 0.47 & 4.00 & 3.00 & \text { “ } \\ 96 & 3.43 & 0.56 & 4.00 & 1.00 & \text { “ } \\ 96 & 3.70 & 0.45 & 4.00 & 3.00 & \text { “ } \\ 96 & 3.68 & 0.51 & 4.00 & 2.00 & \text { " } \\ 96 & 3.50 & 0.50 & 4.00 & 3.00 & \text { Agreed }\end{array}$

to include creation of industrial advisory committee, technical committee, developing administrative practice of industrial liaison offices in technical institutions and formulation of law by the Federal Government to compel cooperation between industries and training institutions.Functional administrative measures should be in forefront of partnership well-designed technical and vocational education. Asiyai [37] found the relevance of administrative approach to include establishment of industrial training centres offices in the higher educational institutions.

Table 3: School-industry approaches for effective work-based learning in EET in Nigeria

\begin{tabular}{|c|c|c|c|c|c|c|c|}
\hline SN & Variables & Obs. & Mean & SD & Max. & Min & Remarks \\
\hline 1 & $\begin{array}{l}\text { Base students' research on solving identified industrial } \\
\text { problem for improved school-industry relations. }\end{array}$ & 96 & 3.62 & 0.56 & 4.00 & 1.00 & Agreed \\
\hline 2 & $\begin{array}{l}\text { Carry out periodic visit of work-based learners on } \\
\text { training for assessment. }\end{array}$ & 96 & 3.35 & 0.48 & 4.00 & 3.00 & 6 \\
\hline 3 & $\begin{array}{l}\text { Institute school-industry relations workshop and } \\
\text { conferences. }\end{array}$ & 96 & 3.28 & 0.61 & 4.00 & 3.00 & 6 \\
\hline 4 & $\begin{array}{l}\text { Organize cross training pattern which involve } \\
\text { technicians from industries and institution. }\end{array}$ & 96 & 3.65 & 0.52 & 4.00 & 3.00 & “ \\
\hline 5 & $\begin{array}{l}\text { Organize cooperative work study programme for } \\
\text { students in the technical institutions. }\end{array}$ & 96 & 3.32 & 0.47 & 4.00 & 3.00 & 6 \\
\hline 6 & $\begin{array}{l}\text { Entering into agreement of joint sharing of training } \\
\text { facilities between industry and institution. }\end{array}$ & 96 & 3.28 & 0.60 & 4.00 & 1.00 & 6 \\
\hline 7 & $\begin{array}{l}\text { Engage technicians in Technical Technology industry } \\
\text { with part-time teaching in technical institutions. }\end{array}$ & 96 & 3.67 & 0.49 & 4.00 & 2.00 & “ \\
\hline 8 & $\begin{array}{l}\text { Engage technical education lecturers to deliver short } \\
\text { training for industry employees. }\end{array}$ & 96 & 3.66 & 0.50 & 4.00 & 2.00 & 6 \\
\hline 9 & $\begin{array}{l}\text { Providing financial support by industry to technical } \\
\text { training institutions. }\end{array}$ & 96 & 3.39 & 0.51 & 4.00 & 2.00 & 6 \\
\hline 10 & $\begin{array}{l}\text { Providing modern facilities, equipment and machines } \\
\text { to training institutions by industry. }\end{array}$ & 96 & 3.65 & 0.49 & 4.00 & 2.00 & Agreed \\
\hline
\end{tabular}

Source: Field Survey, 2019 
The result in Table 3 reveals that the mean ratings of the responses of supervisors and lecturers of Electrical Technology on the 10 identified items ranged from 3.28 to 3.67 which are greater than the criterion reference point of 2.50 on 4-point rating scale. This suggests that the identified 10 items in the table are school-industry approaches that could be utilised for effective WBL in Electrical Technology in Nigeria. Adeyewa [38] reported that cooperation between industry and training institution in placement of students could be automated from the robust database in the enrolment system. The enrolment database essentially becomes a shopping centre for industry or organisations for request for pool of work-based learners. Jimoh, Maigida [36] found that measures towards improving school-industry relationship for effective technical and vocational education include organizing seminar, workshop and conferences to strengthen school-industry relations, and requesting industry to donate equipment to technical institutions for functional work-based learning. More cordial relations between institutions and industry will result to improved training of students. Mohamad, Hamdan [22], based on the report of UNESCO (1996) revealed that school-industry cooperation in host of many countries had been used as an instrument to enhance effectiveness of TVET system. Hence, institution-industry relation should be made cordial to establish proactive synergy in Nigerian technical and vocation education and training.

Table 4: Resource inputs approaches for effective work-based learning in EET in Nigeria

\begin{tabular}{|c|c|c|c|c|c|c|c|}
\hline SN & Variables (Material resource) & Obs. & Mean & SD & Max. & Min. & Remarks \\
\hline 1 & $\begin{array}{l}\text { Adequate funding of work-based learning } \\
\text { programme by the government. }\end{array}$ & 96 & 3.67 & 0.54 & 4.00 & 2.00 & Agreed \\
\hline 2 & $\begin{array}{l}\text { Adequate supply of necessary facilities and } \\
\text { equipment. }\end{array}$ & 96 & 3.66 & 0.47 & 4.00 & 3.00 & “ \\
\hline 3 & $\begin{array}{l}\text { Provision of well-equipped Electrical and } \\
\text { Electronic Technology laboratories in } \\
\text { technical training institutions. }\end{array}$ & 96 & 3.48 & 0.64 & 4.00 & 1.00 & “6 \\
\hline 4 & $\begin{array}{l}\text { Effective repair and maintenance of facilities } \\
\text { and machines for work-based training of } \\
\text { students. }\end{array}$ & 96 & 3.55 & 0.55 & 4.00 & 1.00 & “ \\
\hline 5 & $\begin{array}{l}\text { Replacement of obsolete machines for } \\
\text { effective teaching of students on work-based } \\
\text { learning. } \\
\text { Human resource }\end{array}$ & 96 & 3.44 & 0.49 & 4.00 & 3.00 & Agreed \\
\hline 6 & $\begin{array}{l}\text { Regular in-service training of technicians in } \\
\text { industries and lecturers in training } \\
\text { institutions. }\end{array}$ & 96 & 3.46 & 0.61 & 4.00 & 1.00 & Agreed \\
\hline 7 & $\begin{array}{l}\text { Creating opportunity for foreign training of } \\
\text { personnel. }\end{array}$ & 96 & 3.51 & 0.50 & 4.00 & 3.00 & “ \\
\hline 8 & $\begin{array}{l}\text { Organizing periodic workshop and } \\
\text { conferences for technicians and lecturers for } \\
\text { skill update. }\end{array}$ & 96 & 3.63 & 0.48 & 4.00 & 3.00 & 6 \\
\hline 9 & $\begin{array}{l}\text { Acquisition of higher degrees such as masters } \\
\text { and PhD for lecturers in training institutions. }\end{array}$ & 96 & 3.53 & 0.64 & 4.00 & 1.00 & “ \\
\hline 10 & $\begin{array}{l}\text { ICT training of technicians and lecturers for } \\
\text { effective teaching of students on work-based } \\
\text { learning. }\end{array}$ & 96 & 3.65 & 0.47 & 4.00 & 3.00 & Agreed \\
\hline
\end{tabular}

Source: Field Survey, 2019

The result in Table 4 shows that the mean ratings of the responses of supervisors and lecturers of Electrical Technology on the 10 identified items ranged from 3.44 to 3.67 which are greater than the criterion reference point of 2.50 on 4-point rating scale. This indicates that the identified 10 items in the table are material and human resource input approaches that could be utilised for effective WBL in Electrical Technology in Nigeria.

Human and material resources are central to the development of technical and vocational education and training. Therefore, if work-based learning must be effective for skill acquisition in Nigeria, the human and material resource input contents must be taken seriously. Fund [39] reported that adequate financial resources should be made available to technical and vocational education that adequate funding promotes the provision of essentials materials, facilities and machines to equip laboratories and workshops with relevant textbooks and training manuals. Okoye and Arimonu [7] equally supported that VTE requires skilled and proficient teachers to take instruction in the school. 
The preparation of technicians should be given a priority attention in Nigeria. Hence, there is the need for regular inservice training for instructors or supervisors of TVE to upgrade their skills for effective service delivery for improved technological advancement in the industry.

\section{CONCLUSION}

Work-based learning is a framework in which learners are concurrently required to go through a learning process in a training institution and industry for acquisition of skills and experience in the related industries. Work-based learning is appropriate for use in Nigerian TVET system for the production of craftsmen and technicians with required saleable skills for work. Unfortunately, the present practice of work-based learning framework in TVE in Nigeria is discouraging and not matching the practice of technologically advanced countries of the world. This has resulted into further decay in Nigerian TVE system and continuous production of unemployable TVE graduates due to lack of required skills for work. The situation has further worsened the unemployment rate among the youths resulting in increased insecurity across the country.

To address the situation therefore, this study was carried out to investigate functional approaches for applying workbased learning in Electrical Technology Education in Nigeria. The study found that the present rate of work-based learning practices in Electrical Technology in northwest Nigeria is relatively low. The study therefore identified administrative, school-industry and resource inputs approach for effective application of work-based learning in technical institutions in Nigeria. Hence, the study recommends a purposeful policy be put in place to strengthen a dynamic and robust work-based learning of Electrical and Electronic Technology and other trades of technical and vocation education in Nigeria. That the Nigerian work-based learning framework be carefully developed and overseen by the Industrial Training Unit of education sector to coordinate the synergy between training institutions and industry for improved skill acquisition of the teaming Nigerian youths.

\section{REFERENCES}

1. Brodie, P. and K. Irving, Assessment in work-based learning: investigating a pedagogical approach to enhance student learning. Assessment \& Evaluation in Higher Education, 2007. 32(1): p. 11-19.

2. Ismail, S., et al., A Comparison of the work-based learning models and implementation in training institutions. Procedia-Social and Behavioral Sciences, 2015. 204: p. 282-289.

3. Monroe Career and Technical Institute Electrical Technology. MCTI,2018 20th September, 2018]; Available from: https://www.monroecti.org/.

4. Aggeliki, K., What is Electrical and Electronic Technology? 2019.

5. Aderonmu, P., A Framework for Sustainable Education in Nigeria: Strategies of Re-Integrating Vocational Skills into Educational Curriculum. A Framework for Sustainable Education in Nigeria: Strategies of Reintegrating Vocational Skills into Educational Curriculum, 2012: p. 1-24.
6. Okoro, M.O., Principles and Methods in Vocational and Teaching Education. 2006, Nsukka: University trust publishers.

7. Okoye, R. and M.O. Arimonu, Technical and Vocational Education in Nigeria: Issues, Challenges and a Way Forward. Journal of Education and Practice, 2016. 7(3): p. 113-118.

8. Oranu, R.N., Vocational and Technical Education in Nigeria. 2004.

9. Oryem-Origa, S., Vocational education and manpower development. Lagos: Nigerian Vocational association monograph series, 2005.

10. Ezeji, H.A., N.I. Edeh, and E.A. Etonyeaku, Effective Implementation of TVET-Industry Partnership for Employability of Graduates through Work Integrated Learning in Nigerian Universities. Review of European Studies, 2016. 8(3): p. 307.

11. National Population Commission, The Provisional Population of Nigeria. NPC 2006: Abuja, Nigeria.

12. Bubou, G.M., I.T. Offor, and S. Gumus, An argument for the practice of evidence-based teaching in engineering education for developing countries with focus on Nigerian universities. QScience Proceedings, 2015: p. 26.

13. Ajufo, B.I., Challenges of youth unemployment in Nigeria: Effective career guidance as a panacea. African Research Review, 2013. 7(1): p. 307-321.

14. Onu, A., Stimulating Entrepreneurship in Educational Institutions in Nigeria. European Scientific Journal, 2013. 9(25).

15. Okon, U. Work-Based Learning initiatives. in StepB/World Bank-assisted TVET Teachers Upskilling workshop held at the University of Nigeria, Nsukka from 23rdOctober-4th November. 2011.

16. Jerrard, R. and M. Jefsioutine, Reflections on using online contracts for work-based learning and teaching in art and design. Art, Design \& Communication in Higher Education, 2006. 5(1): p. 55-69.

17. Amadi, U.P., Appraising Work-Based Learning Experiences of Technical and Vocational (Teacher) Educationand Training (TVTET) Programmes In Nigeria. Mediterranean Journal of Social Sciences, 2013. 4(5): p. 137.

18. Kamin, Y.B., et al., Work-Based Learning: Employer Perspective Towards the Automotive Industry. Advanced Science Letters, 2018. 24(4): p. 2518-2521.

19. Schrenko, L.C., Standards and Guidelines for WorkBased Learning Programmes in Georgia. State of Georgia Department of Education, 2010.

20. Virginia Department of Education, Career and Technical Education Work-Based Learning. . 2018.

21. Boud, D. and N. Solomon, Work-based learning: a new higher education? 2001: McGraw-Hill Education (UK).

22. Mohamad, N.H.B., H.B. Hamdan, and R. Douni, Workbased Learning-Revisiting Its Nature and Requirements. Politeknik \& Kolej Komuniti Journal of Social Sciences and Humanities, 2016. 1(1).

23. Lemanski, T., R. Mewis, and T. Overton, An introduction to work-based learning. 2011: Higher Education Academy, UK Physical Sciences Centre.

24. Becker, K., Digital game-based learning once removed: Teaching teachers. British Journal of Educational Technology, 2007. 38(3): p. 478-488.

25. Fleming, J. and A. Martin, Facilitating reflective learning journeys in sport cooperative education. Journal of Hospitality, Sport, Tourism, Leisure and Education, 2007. 6(2): p. 115-121. 
26. White, T., Employer responsive provision: workforce development through work-based learning. Higher Education, Skills and Work-Based Learning, 2012. 2(1): p. 6-21.

27. Co-operation, O.f.E. and Development, From initial education to working life: making transitions work: preliminary edition. 2000.

28. Deitmer, L., Building up the innovative capabilities of workers. Fostering Enterprise: The Innovation and Skills Nexus-Research Readings. Adelaide, Australia, National Centre for Vocational Education Research (NCVER), 2011: p. 38-51.

29. Stainsby, K. and K. Bannigan, Reviewing work-based learning opportunities in the community for physiotherapy students: an action research study. Journal of Further and Higher Education, 2012. 36(4): p. 459476.

30. Rauner, F. and E. Smith, Rediscovering apprenticeship: Research findings of the international network on innovative apprenticeship (INAP). Vol. 11. 2010: Springer Science \& Business Media.

31. Check, J. and R.K. Schutt, Survey research. Research methods in education, 2012: p. 159-185.

32. Ponto, J., Understanding and evaluating survey research. Journal of the advanced practitioner in oncology, 2015. 6(2): p. 168.

33. Onipede, O., Assessment of the Effectiveness of Resource Inputs into the Implementation of Agricultural Education Programme in Colleges of Education in Southwest Nigeria, in Agricultural Education. 2013, University of Nigeria, Nsukka.

34. Mark, S.A., The Teaching and Learning of Technical and Vocational Education in Nigeria. Nigerian Journal of Technical Education, 2016. 8(2): p. 221-236.

35. Amaechi, O.J. and C.G. Thomas, Strategies of Effective Teaching and Learning Practical Skills in Technical and Vocational Training Programmes in Nigeria. International Journal of Scientific Research Engineering \& Technology (IJSRET), 2016. 5(12): p. 598-603.

36. Jimoh, J., J. Maigida, and S. Adebayo, Strategies for Improving School-Industry Relations for Effective Work Preparation of Automomobile Technology Students in the Technical Institutions in Lagos State. Review of Education Institute of Education Journal, 2012. 23(1): p. 137-155.

37. Asiyai, R.I., Improving Quality Higher Education in Nigeria: The Roles of Stakeholders. International Journal of higher education, 2015. 4(1): p. 61-70.

38. Adeyewa, Z.D., Modernizing the Operations of the SIWES Programme: The Role of ITU and other Stakeholders., in Maiden Edition of the Annual Lecture Series of the Industrial Training Unit. 2015: Federal University of Technology, Akure.

39. Fund, I.T., Students Industrial Work Experience Scheme: Information and guideline for SIWES. 2013, Ruche Press: Jos.

\section{AUTHOR'S PROFILE}

Rabiu Haruna was born in Kano, Nigeria. $\mathrm{He}$ received his B. Tech (Ed) Electrical from Federal University of Technology Minna and M.Sc. degree in Electronic and Information Engineering from Huazhong University of Science and Technology, China. He is currently working towards PhD degree in Department of Technical and Engineering Education, School of Education, Universiti Teknologi Malaysia. He is a registered member of IEEE, TRCN, IET and IVETA. His current research interests are in the areas of Technical and Vocational Education, Workbased Learning and Electrical Technology Education. 